\title{
Weight loss improves biomarkers endothelial function and systemic inflammation in obese postmenopausal Saudi women.
}

\author{
Shehab Mahmoud Abd El- Kader ${ }^{1}$, Mohammed H Saiem Al-Dahr²
}

1. Department of Physical Therapy, Faculty of Applied Medical Sciences, King Abdulaziz University.

2. Department of Medical Laboratory Technology, Faculty of Applied Medical Sciences, King Abdulaziz University.

\begin{abstract}
Background: Although postmenopausal associated disorders are important public health problems worldwide, to date limited studies evaluated the endothelial function and systemic inflammation response to weight loss in obese postmenopausal women. Objective: This study was done to evaluate the endothelial function and systemic inflammation response to weight loss in obese postmenopausal Saudi women.

Material and methods: Eighty postmenopausal obese Saudi women (mean age 52.64 \pm 6.13 year) participated in two groups: Group (A) received aerobic exercise on treadmill and diet whereas, group (B) received no intervention. Markers of inflammation and endothelial function were measured before and after 3 months at the end of the study.

Results: The values of body mass index(BMI), interleukin-6 (IL-6), tumor necrosis factor-alpha (TNF- $\alpha$ ), C-reactive protein (CRP), inter-cellular adhesion molecule (ICAM-1), vascular cell adhesion molecule (VCAM-1) and plasminogen activator inhibitor-1 activity (PAI-1:Ac) were significantly decreased in group (A), while changes were not significant in group (B). Also, there were significant differences between mean levels of the investigated parameters in group (A) and group (B) after treatment.

Conclusion: Weight loss ameliorates inflammatory cytokines and markers of endothelial function in obese postmenopausal Saudi women.
\end{abstract}

Keywords: Menopause, cytokines, endothelial function, exercise, diet.

DOI: http://dx.doi.org/10.4314/ahs.v16i2.22

Cite as: Abd El-Kader SM, Al-Dabr MHS. Weight loss improves biomarkers of endothelial function and systemic inflammation in obese postmenopausal Saudi women. Afri Health Sci 2016;16(2): 533-541. bttp://dx.doi.org/10.4314/abs.v16i2.22

\section{Introduction}

Globally, the number of menopausal women is increased as the proportion of geriatric population is expected to be increased from $12 \%$ up to $20 \%$ by $2050^{1,2}$ correlated with increased prevalence of obesity, which is currently considered to be an epidemic ${ }^{3}$ as obesity and overweight affect about two-third of population worldwide ${ }^{4}$. Obesity has many co-morbidities as cancer, osteoarthritis, cardiovascular, respiratory and type 2 diabetes $^{5-8}$.

\footnotetext{
Corresponding author:

Shehab Mahmoud Abd El- Kader, Faculty of Applied Medical Sciences, Department of Physical Therapy, King Abdulaziz University, P.O. Box 80324, Jeddah, 21589,Saudi Arabia. Phone: +966-569849276

Email: salmuzain@kau.edu.sa
}

Endothelial dysfunction is considered as an early predictor of various cardiovascular disorders such as atherosclerosis and heart attack and has been implicated in the pathogenesis of diabetes-induced angiopathy'. Atherosclerosis is a leading cause of morbidity includes peripheral vascular disorders, stroke and ischemic heart disease, however, and mortality in diabetic patients. Endothelial dysfunction is considered an initial dysfunction of blood vessels and an important predictor of atherosclerosis in diabetic patients ${ }^{10-12}$.

Aerobic exercises associated with appropriate diet regimen were reported to protect against atherosclerosis in non-insulin dependent diabetes mellitus ${ }^{13}$. However, weight reduction program modulates markers of systemic inflammation, endothelial function and adipokines which are usually associated with better cardiovascular system prognosis in obese subjects ${ }^{14,15}$.

The aim of this study was to evaluate the endothelial function and systemic inflammation response to weight loss in obese postmenopausal Saudi women. 


\section{Materials and methods}

\section{Subjects}

Eighty obese postmenopausal Saudi women were enrolled in the present randomized controlled trial, andwere selected from the Internal Medicine Department at King Abdul Aziz University Hospital and other Hospitals in Jeddah area. Inclusion criteria of this study were the following: (1) postmenopausal women aged 47-58 years; (2) a sedentary lifestyle (not exercising $>30$ minutes on $>3$ day/week) for the past 6 months; and (3) not taking any medication including lipid lowering agents, nonsteroidal anti-inflammatory drugs, antihypertension drugs, and hormone-replacement therapy. Exclusion criteria included patients suffering from congestive heart failure; uncontrollable cardiac arrhythmias, hypertension, musculoskeletal disorders, and intake of medications affect the endothelial function. Participants were sub divided into two groups; group (A) received treadmill aerobic exercise training and diet regimen. Group (B) received no exercise training and no diet regimen. The original sample consisted of 184 participants who underwent the eligibility assessment. In the enrollment phase, 63 of them were excluded as they didn't meet inclusion criteria and 18 refused to participate, then randomization was done. This substudy thus included 103 subjects (53 patients in the intervention group and 50 patients in the control group). During the follow up, in the intervention group $7 \mathrm{pa}-$ tients discontinued intervention (4 patients disliked the diet regimen, 2 patients had work related schedule problems and 1 patient discontinued due to unknown reason) and in the control group 6 patients discontinued intervention (4 patients had work related schedule problems and 2 patient discontinued due to unknown reasons).In addition, 6 patients in the intervention group and 4 patients in the control group were excluded from the analysis due to insufficient blood sample. This study was approved by the Ethical Committee for Scientific Research, Faculty of Applied Medical Sciences, King Abdulaziz University. All participants provided written informed consent.

\section{Measurements}

A. Measurement of biomarkers of endothelial function: Biomarkers of endothelial function included adhesion molecules which included inter-cellular adhesion molecule (ICAM-1), vascular cell adhesion molecule (VCAM-1) and the fibrinolytic molecule (plasminogen activator inhibitor-1 activity, PAI-1:Ac). These were measured from frozen serum samples stored at $-80{ }^{\circ} \mathrm{C}$.
Enzyme-linked immunosorbent assays(ELISAs) were used to measure soluble levels of ICAM-1 and VCAM-1 (R\&D Systems, USA), and PAI-1: Ac (Hyphen BioMed for PAI-1, France).

B. Measurement of inflammatory cytokines: Venous blood samples after a 12-hours fasting were centrifuged at $4{ }^{\circ} \mathrm{C}(1000=\mathrm{g}$ for $10 \mathrm{~min})$. Interleukin-6 (IL-6) levels were analyzed by "Immulite 2000 " immunassay analyzer (Siemens Healthcare Diagnostics, Deerfield, USA). However, tumor necrosis factor-alpha $(\mathrm{TNF}-\alpha)$ and $\mathrm{C}$-reactive protein (CRP) levels were measured by ELISA kits (R\&D, USA) by using ELISA technique (ELX 808; Bio'Tek Instruments, USA).

C. Measurement of Anthropometric Parameters: For all participants their height was measured with a digital stadio-meter to the nearest $0.1 \mathrm{~cm}$ (JENIX DS 102, S. Korea). The participants were measured while wearing their undergarments and hospital gowns. Body weight was measured on a calibrated balance scale to the nearest $0.1 \mathrm{~kg}$ (HC4211, S. Korea), and body mass index (BMI) was calculated as body weight/Height ${ }^{2}$.

All measurements of BMI, IL-6, TNF- $\alpha$, CRP, ICAM-1, VCAM-1 and PAI-1: Ac were taken before the starting of the study (pre-test) and after three months at the end of the study (post-test).

\section{Procedures}

All patients were divided randomly into the following groups:

1. The training group (Group A): Patients were submitted to the aerobic exercise training to complete a 12 -week aerobic exercise-training program on a treadmill aerobic exercise (Enraf Nonium, Model display panel Standard, NR 1475.801, Holland). Each session of physical exercise was divided in: 5 minutes of warm up, with stretching exercises and circling of members and body; 30 minutes of aerobic exercise divided into row ergometer (15 minutes) and bicycle ergometer ( 15 minutes) and 5 minutes of cold down at the end, with stretching, flexibility and relaxation exercises, consisting of five sessions per week. The training program was performed at $70 \%$ of the individual agepredicted $\mathrm{HR}_{\max }{ }^{16}$. In addition, a dietician performed an interview-based food survey for all participants of group (A) for detection of feeding habits, abnormal dietary behavior and to prescribe the balanced low calorie that provide 1200 kilocalories/day for 12 weeks. 
2. The control group (Group B): Patients maintained their ordinary life style and received no exercise and diet regimen training.

\section{Statistical analysis}

All results are shown as means $\pm \mathrm{SD}$. The mean values of the investigated parameters obtained before and af- ter training program in both groups were compared using paired " $\mathrm{t}$ " test. Independent " $\mathrm{t}$ " test was used for the comparison between the two groups $(\mathrm{P}<0.05)$.

\section{Results}

The two groups were considered homogeneous regarding the baseline clinical variables (Table 1).

\section{Table (1): Baseline clinical participants' characteristics in both groups.}

\begin{tabular}{|l|c|c|c|}
\hline & \multicolumn{2}{|c|}{ Mean \pm SD } & \multirow{2}{*}{ Significance } \\
\cline { 2 - 3 } & $\begin{array}{c}\text { Intervention group } \\
(\mathbf{n}=\mathbf{4 0})\end{array}$ & $\begin{array}{c}\text { Control group } \\
(\mathbf{n}=\mathbf{4 0})\end{array}$ & \\
\hline Age $($ year$)$ & $51.17 \pm 5.63$ & $50.41 \pm 5.27$ & $\mathrm{P}>0.05$ \\
\hline Weight $(\mathrm{kg})$ & $90.82 \pm 6.84$ & $91.13 \pm 6.51$ & $\mathrm{P}>0.05$ \\
\hline Height $(\mathrm{cm})$ & $168.93 \pm 7.72$ & $170.76 \pm 8.15$ & $\mathrm{P}>0.05$ \\
\hline Waist-hip ratio & $0.85 \pm 0.07$ & $0.87 \pm 0.08$ & $\mathrm{P}>0.05$ \\
\hline BMI $\left(\mathrm{kg} / \mathrm{m}^{2}\right)$ & $33.71 \pm 3.12$ & $34.11 \pm 3.54$ & $\mathrm{P}>0.05$ \\
\hline SBP $(\mathrm{mm} \mathrm{Hg})$ & $122.56 \pm 8.17$ & $124.18 \pm 7.96$ & $\mathrm{P}>0.05$ \\
\hline DBP $(\mathrm{mm} \mathrm{Hg})$ & $83.42 \pm 4.31$ & $84.21 \pm 4.92$ & $\mathrm{P}>0.05$ \\
\hline TC $(\mathrm{mg} / \mathrm{dl})$ & $195.35 \pm 10.32$ & $197.14 \pm 11.18$ & $\mathrm{P}>0.05$ \\
\hline LDL-c $(\mathrm{mg} / \mathrm{dl})$ & $134.44 \pm 8.91$ & $135.32 \pm 8.87$ & $\mathrm{P}>0.05$ \\
\hline TG $(\mathrm{mg} / \mathrm{dl})$ & $155.20 \pm 10.41$ & $157.16 \pm 10.16$ & $\mathrm{P}>0.05$ \\
\hline HDL-c $(\mathrm{mg} / \mathrm{dl})$ & $36.31 \pm 2.97$ & $35.94 \pm 2.85$ & $\mathrm{P}>0.05$ \\
\hline HOMA-IR & $2.87 \pm 2.62$ & $2.76 \pm 2.81$ & $\mathrm{P}>0.05$ \\
\hline
\end{tabular}

BMI: Body mass index; SBP: Systolic blood pressure; DBP: Diastolic blood pressure; TC: Total cholesterol; HOMA-IR: Homeostasis Model Assessment-Insulin Resistance Index; LDL-c: Low-density lipoprotein cholesterol; TG: Triglyceride; HDL-c: High-density lipoprotein cholesterol.

There was a $36.9 \%, 48.8 \%, 43.1 \%, 9.8 \%, 10.7 \%, 25.9 \%$ and $10.5 \%$ reduction in mean values of IL- $6, \mathrm{TNF}^{-} \alpha$, CRP, ICAM-1, VCAM-1, PAI-1and BMI respectively in group (A) at the end of the study. The mean value of BMI, IL-6, TNF- $\alpha$, CRP, ICAM-1, VCAM-1 and PAI1: Ac was significantly decreased in group (A) (Table 2), while changes were not significant in group (B) (Table 3). 
Table (2): Mean value and significance of BMI, TNF- $\alpha$, IL-6, CRP, ICAM-1, VCAM-1 and PAI-1: Ac in group (A) before and at the end of the study.

\begin{tabular}{|l|c|c|c|}
\hline & \multicolumn{2}{|c|}{ Mean \pm SD } & \multirow{2}{*}{ Significance } \\
\cline { 2 - 3 } & Before the study & At the end of the study & \\
\hline BMI $\left(\mathrm{kg} / \mathrm{m}^{2}\right)$ & $33.71 \pm 3.12$ & $30.17 \pm 2.98^{*}$ & $\mathrm{P}<0.05$ \\
\hline TNF- $\boldsymbol{\alpha}(\mathrm{pg} / \mathrm{mL})$ & $12.85 \pm 2.74$ & $8.11 \pm 2.65^{*}$ & $\mathrm{P}<0.05$ \\
\hline IL-6 $(\mathrm{pg} / \mathrm{mL})$ & $5.63 \pm 1.42$ & $3.16 \pm 1.36^{*}$ & $\mathrm{P}<0.05$ \\
\hline CRP $(\mathrm{mg} / \mathrm{L})$ & $4.13 \pm 1.13$ & $2.35 \pm 0.97^{*}$ & $\mathrm{P}<0.05$ \\
\hline ICAM-1 $(\mathrm{ng} / \mathrm{ml})$ & $93.78 \pm 16.93$ & $84.54 \pm 15.16^{*}$ & $\mathrm{P}<0.05$ \\
\hline VCAM-1 $(\mathrm{ng} / \mathrm{ml})$ & $821.93 \pm 54.98$ & $734.22 \pm 51.73^{*}$ & $\mathrm{P}<0.05$ \\
\hline PAI-1: $\mathbf{A c}(\mathrm{ng} / \mathrm{ml})$ & $0.54 \pm 0.17$ & $0.40 \pm 0.13^{*}$ & $\mathrm{P}<0.05$ \\
\hline
\end{tabular}

BMI: Body mass index; TNF- $\alpha$ : tumor necrosis factor - alpha; IL-6: Interleukin-6; CRP: C- reactive protein; ICAM-1: Inter-Cellular Adhesion Molecule; VCAM-1: Vascular Cell Adhesion Molecule; PAI-1: Ac: Plasminogen Activator Inhibitor-1 Activity; $(*)$ indicates a significant difference between the two groups, $\mathrm{P}<0.05$.

Table (3): Mean value and significance of BMI, TNF- $\alpha$, IL-6, CRP, ICAM-1, VCAM-1 and PAI-1: Ac in group (B) before and at the end of the study.

\begin{tabular}{|l|c|c|c|}
\hline & \multicolumn{2}{|c|}{ Mean +SD } & \multirow{2}{*}{ Significance } \\
\cline { 2 - 3 } & Before the study & At the end of the study & \\
\hline BMI $\left(\mathrm{kg} / \mathrm{m}^{2}\right)$ & $34.11 \pm 3.54$ & $34.31 \pm 3.59$ & $\mathrm{P}>0.05$ \\
\hline TNF- $\boldsymbol{\alpha}(\mathrm{pg} / \mathrm{mL})$ & $12.96 \pm 2.65$ & $12.12 \pm 2.74$ & $\mathrm{P}>0.05$ \\
\hline IL-6 $(\mathrm{pg} / \mathrm{mL})$ & $5.89 \pm 1.58$ & $5.93 \pm 1.60$ & $\mathrm{P}>0.05$ \\
\hline CRP $(\mathrm{mg} / \mathrm{L})$ & $4.53 \pm 1.27$ & $4.58 \pm 1.28$ & $\mathrm{P}>0.05$ \\
\hline ICAM-1 $(\mathrm{ng} / \mathrm{ml})$ & $94.16 \pm 14.52$ & $94.25 \pm 14.57$ & $\mathrm{P}>0.05$ \\
\hline VCAM-1 $(\mathrm{ng} / \mathrm{ml})$ & $825.12 \pm 52.74$ & $826.81 \pm 52.69$ & $\mathrm{P}>0.05$ \\
\hline PAI-1: $\mathbf{A c}(\mathrm{ng} / \mathrm{ml})$ & $0.58 \pm 0.19$ & $0.62 \pm 0.21$ & $\mathrm{P}>0.05$ \\
\hline
\end{tabular}

BMI: Body mass index; TNF- $\alpha$ : tumor necrosis factor - alpha; IL-6: Interleukin-6; CRP: C- reactive protein; ICAM-1: Inter-Cellular Adhesion Molecule; VCAM-1: Vascular Cell Adhesion Molecule; PAI-1: Ac: Plasminogen

In addition, there were significant differences between mean levels of the investigated parameters in group (A)

and group (B) at the end of the study (Table 4). 


\section{Table (4): Mean value and significance of BMI, TNF- $\alpha$, IL-6, CRP, ICAM-1, VCAM-1 and PAI-1: Ac in group (A) and group (B) at the end of the study.}

\begin{tabular}{|l|c|c|c|}
\hline & \multicolumn{2}{|c|}{ Mean +SD } & \multirow{2}{*}{ Significance } \\
\cline { 2 - 3 } & Group (A) & Group (B) & \\
\hline BMI $\left(\mathrm{kg} / \mathrm{m}^{2}\right)$ & $30.17 \pm 2.98^{*}$ & $34.31 \pm 3.59$ & $\mathrm{P}<0.05$ \\
\hline TNF- $\boldsymbol{\alpha}(\mathrm{pg} / \mathrm{mL})$ & $8.11 \pm 2.65^{*}$ & $12.12 \pm 2.74$ & $\mathrm{P}<0.05$ \\
\hline IL-6 $(\mathrm{pg} / \mathrm{mL})$ & $3.16 \pm 1.36^{*}$ & $5.93 \pm 1.60$ & $\mathrm{P}<0.05$ \\
\hline CRP $(\mathrm{mg} / \mathrm{L})$ & $2.35 \pm 0.97^{*}$ & $4.58 \pm 1.28$ & $\mathrm{P}<0.05$ \\
\hline ICAM-1 $(\mathrm{ng} / \mathrm{ml})$ & $84.54 \pm 15.16^{*}$ & $94.25 \pm 14.57$ & $\mathrm{P}<0.05$ \\
\hline VCAM-1 $(\mathrm{ng} / \mathrm{ml})$ & $734.22 \pm 51.73^{*}$ & $826.81 \pm 52.69$ & $\mathrm{P}<0.05$ \\
\hline PAI-1: $\mathbf{A c}(\mathrm{ng} / \mathrm{ml})$ & $0.40 \pm 0.13^{*}$ & $0.62 \pm 0.21$ & $\mathrm{P}<0.05$ \\
\hline
\end{tabular}

BMI: Body mass index; TNF- $\alpha$ : tumor necrosis factor - alpha; IL-6: Interleukin-6; CRP: C- reactive protein; ICAM-1: Inter-Cellular Adhesion Molecule; VCAM-1: Vascular Cell Adhesion Molecule; PAI-1: Ac: Plasminogen Activator Inhibitor-1 Activity; (*) indicates a significant difference between the two groups, $\mathrm{P}<0.05$.

\section{Discussion}

There is a high prevalence of obesity among Saudi postmenopausal women that reached $39.3 \%$ among diabetics as compared to $18.5 \%$ among non-diabetics ${ }^{17}$. The population of Saudi Arabia with changes in lifestyle, reduction of physical activity and high calorie snacks and foods have led to increased prevalence of obesity ${ }^{18}$. Obesity is an independent risk factor for cardiovascular disorders that may be related to abnormal levels of inflammatory cytokines and endothelial dysfunction ${ }^{10-12}$.

The American Heart Association recommended weight loss to reduce the severity of cardiovascular risk factors in overweight and obese patients ${ }^{19}$. However, little is known about the effect of lifestyle intervention on inflammatory cytokines and circulating levels of endothelial function biomarkers among obese postmenopausal Saudi women. The main finding of the present study was that weightreducing program ameliorated inflammatory cytokines (TNF- $\alpha$, IL-6 and CRP) and markers of endothelial function (ICAM-1 VCAM-1 and tPA) in obese postmenopausal women as a result of weight loss, these results are in line with many previous studies. Cotie and colleagues demonstrated that, sixteen weeks of a combined training by aerobic and resistance exercises in addition to diet resulted in improved interleukin-6 (IL-6) and endothelial function in overweight and obese young women because of weight loss ${ }^{20}$.
Lang and colleagues established that a weight-reducing program had anti-atherogenic and inflammatory effects in their study on three obese men and eleven obese women for eight weeks ${ }^{21}$. Choo and colleagues proved that weight-reducing program in the form of diet regimen for three months followed by diet regimen added to exercise intervention for nine months had a remarkable reduction in the risk of cardio-metabolic and subclinical atherosclerosis $^{22}$. Madsen and colleagues stated that inflammatory markers were reduced significantly if body weight was reduced by $10 \%$ in obese subjects ${ }^{23}$. Esposito et al. suggested that weight-reducing program for 2 years significantly reduced C-reactive protein ${ }^{24}$. In addition, Nicklas and colleagues stated that 12 months life style modification program significantly reduced TNF- $\alpha$ level in obese individuals ${ }^{25}$. Loria-Kohen and colleagues conducted their study on 84 overweight participants completed 22 weeks of different exercises programs in addition to diet control. The CRP and TNF- $\alpha$ have shown reduction values in all study groups ${ }^{26}$.

Sheu and colleagues reported that $5 \%$ of body weight loss obtained after 12 weeks of caloric restriction and exercises resulted in significant reduction in $\mathrm{TNF}-\alpha$ and IL-6 of obese women ${ }^{27}$. However, Rokling-Andersen and colleagues studied the impact of one-year diet regimen alone or in association with exercises and found a significant improvement in TNF- $\alpha$ and adiponectin ${ }^{28}$ and CRP 
in both groups. Silverman and colleagues conducted their study on obese postmenopausal women who participated in a six months hypo-caloric diet or hypo-caloric diet plus walking program, they concluded that addition of aerobic exercises to hypo-caloric diet is recommended to modulate TNF- $\alpha$ and IL- 6 and increase bone marrow density ${ }^{29}$. Imayama and colleagues examined the effects of a caloric restriction weight loss diet and exercise on inflammatory biomarkers in 439 obese postmenopausal women were randomized to one year: caloric restriction diet (goal of $10 \%$ weight loss, $\mathrm{N}=118$ ), aerobic exercise (225 minutes/ week of moderate-to-vigorous activity, $\mathrm{N}=117$ ), combined diet plus exercise $(\mathrm{N}=117)$ or control $(\mathrm{N}=87)$, findings indicated that a caloric restriction weight loss diet with or without exercise reduces biomarkers of inflammation (CRP and IL-6) in postmenopausal women ${ }^{30}$. Garanty-Bogacka et al. applied a study on fifty six obese adolescents, participating in an obesity intervention program, they were studied before and after 1 year program consisting of moderate physical activity (exercise group including 37 participants) or hypo-caloric diet (diet group: 19 subjects) and concluded that moderate-intensity training alone reduced IL- 6 and CRP in obese adolescents more than observed after caloric restriction ${ }^{31}$. In addition, bariatric surgery decreased CRP ,IL-6 and increased the circulating level of adiponectin ${ }^{32-36}$. Reductions in proinflammatory cytokines concentrations after weight loss is explained by reduction in fat mass ${ }^{37}$.

Concerning the markers of endothelial function, the observation in this study indicated a significant reduction in VCAM-1, ICAM-1 and PAI-1 because of weight loss at the end of the study. Nevertheless, the current data is in line with many studies conducted in obese subjects having observed reduction in PAI-1 ${ }^{38-41}$, VCAM- ${ }^{41}$ and ICAM$1^{41-43}$ following weight loss. Sharman and Volek concluded that a six weeks hypo-caloric diet resulted in reduction in ICAM-1, CRP, IL-6, TNF- $\alpha^{44}$ and PAI-1 after 12 weeks in overweight subjects ${ }^{45}$. Thomson and colleagues prove that a 12 week of hypo-caloric diet of high protein diet with or without exercise training resulted in significant reduction in ICAM-1, VCAM-1 and PAI-1 levels associated with weight loss in obese women with polycystic ovary syndrome ${ }^{46}$. Haspicova and colleagues conducted a study on forty obese premenopausal women had reduction in plasma VCAM-1 and ICAM-1 because of 4-week very low caloric diet $(800 \mathrm{kcal} / \text { day })^{47}$. Furthermore, there is indirect evidence based on plasma markers ICAM and Eselectin that were improved by weight-loss ${ }^{48}$. In addition, bariatric surgery resulted in improvement in endothelial function ${ }^{49,50}$. The mechanisms of endothelial dysfunction modulation are not clearly elucidated, however many studies suggest that reduction in oxidative stress and markers of endothelial activation ${ }^{51,52}$ as well as increases in nitrous oxide bioavailability through repeated increase of shear stressmayserve as mechanisms ${ }^{53,54}$.

The current study has important strengths and limitations. The major strength is the supervised nature of the study. Supervising food intake and physical activity removes the need to question compliance or to rely on food and activity questionnaires. Furthermore, all exercise sessions were supervised and adherence to the diet and activities was essentially 100\%. Moreover, the study was randomized; hence, we can extrapolate adherence to the general population. On the other hand, the major limitation is only postmenopausal women enrolled in the study, so the value of this study only related to women in this age group, also a small sample size in both groups may limit the possibility of generalization of the findings in the present study. Finally, within the limit of this study, weight reduction is recommended for modulation of low grade systemic inflammation and endothelial dysfunction among obese postmenopausal women. Further researches are needed to explore the impact of weight reduction on quality of life and other biochemical parameters among postmenopausal women.

\section{Conclusion}

Weight loss ameliorates inflammatory cytokines and markers of endothelial function in obese postmenopausal Saudi women.

\section{Acknowledgment}

This project was funded by the Deanship of Scientific Research (DSR), King Abdulaziz University, Jeddah, under grant no. (142/498/D1435). The authors, therefore, acknowledge with thanks DSR technical and financial support.

\section{References}

1. Arterburn D, Crane P, Sullivan S. The coming epidemic of obesity in elderly Americans. J Am Geriatr Soc 2004; 52:1907-1912. 
2. Yan L, Daviglus M, Liu K. BMI and health-related quality of life in adults 65 years and older. Obes Res 2004; 12:69-76.

3. Fuller N., Lau N., Denyer G., Simpson A., Gerofi J., Wu M., Holmes A., Markovic T., Kang J. and Caterson I. A 12-week, randomised, controlled trial to examine the acceptability of the Korean diet and its effectiveness on weight and metabolic parameters in an Australian overweight and obese population. Obesity Research \& Clinical Practice 2012; 6(1):71-83.

4. Flegal K, Carroll M, Ogden C, Curtin L. Prevalence and trends in obesity among US adults, 1999-2008. JAMA 2010; 303(3):235-241.

5. Avenell A, Broom J, Brown T, Poobalan A, Aucott L, Stearns S, Smith W, Jung R, Campbell M, Grant A. Systematic review of the long-term effects and economic consequences of treatments for obesity and implications for health improvement. Health Technol Assess 2004; 8(21):1-182.

6. Kruger, J, Bowles H, Jones D, Ainsworth B, Kohl H. Health-related quality of life, BMI and physical activity among US adults ( $\mathrm{N}=18$ years): National physical activity and weight loss survey, 2002. International Journal of Obesity 2007; 31, 321-327.

7. Stevenson J. Metabolic profile and cardiovascular system through menopause and ageing: impact on quality of life. Proceedings of 6th IMS Workshop: Menopause and Ageing, Quality of Life and Sexuality; Pisa, Italy 2006: 1-4: 1-7.

8. Netjasov A, Vujović S, Ivović M, Tančić-Gajić M, Marina L, Barać M. Relationships between Obesity, Lipids and Fasting Glucose in the Menopause. Srp Arh Celok Lek 2013; 141(1-2):41-47.

9. Davignon J, Ganz P. Role of endothelial dysfunction in atherosclerosis. Circulation 2004; 109 (23 Suppl 1):III2732.

10. Madhu S. Endothelial Dysfunction and Diabetes. JAPI 2010; 58: 475-476 PubMed.

11. Xu J, Zou M. Molecular insights and therapeutic $\operatorname{tar}\urcorner$ gets for diabetic endothelial dysfunction. Circulation 2009; 120: 1266-1286.

12. Tabit C, Chung W, Hamburg N. Endothelial dysfunc $\neg$ tion in diabetes mellitus: molecular mechanisms and clinical implications. Rev Endocr Metab Disord 2010; 11: 61-74.

13. Brandt C, Pedersen B. The role of exercise-induced myokines in muscle homeostasis and the defense against chronic diseases. J Biomed Biotechnol 2010, 25: 520-528 PubMed.

14. Taddei S, Ghiadoni L, Salvetti G, Virdis A, Salvetti A. Obesity and endothelial dysfunction. G Ital Cardiol (Rome) 2006; 7(11):715-23.

15. Jorge M, de Oliveira V, Resende N, Paraiso L, Calixto A, Diniz A. The effects of aerobic, resistance, and combined exercise on metabolic control, inflammatory markers, adipocytokines,and muscle insulin signaling in patients with type 2 diabetes mellitus. Metabolism 2011; 60: 1244-1252

16. Tanaka H, Monahan K, Seals D. Age-predicted maximal heart rate revisited. J Am Coll Cardiol 2001; 37: 153156.

17. El-Hazmi MA, Warsy AS. Obesity and overweight in Type II diabetes mellitus patients in Saudi Arabia. Saudi medical journal 1999;20:167-172.

18. Al-Nuaim AR. Population based epidemiological study of the prevalence of overweight and obesity in Saudi Arabia, regional variation. Ann Saudi Med 1997;17:1959 PubMed.

19. Klein S, Burke LE, Bray GA. Clinical implications of obesity with specific focus on cardiovascular disease: a statement for professionals from the American Heart Association Council on Nutrition, Physical Activity, and Metabolism: Endorsed by the American College of Cardiology Foundation. Circulation 2004; 110:2952-2967 PubMed.

20. Cotie LM, Josse AR, Phillips SM, MacDonald MJ. Endothelial function increases after a 16-week diet and exercise intervention in overweight and obese young women. Biomed Res Int 2014; 2014:327395.

21. Lang HF, Chou CY, Sheu WH, Lin JY. Weight loss increased serum adiponectin but decreased lipid levels in obese subjects whose body mass index was lower than 30 $\mathrm{kg} / \mathrm{m}^{2}$. Nutr Res 2011; 31(5):378-86.

22. Choo J, Lee J, Cho JH, Burke LE, Sekikawa A, Jae SY. Effects of weight management by exercise modes on markers of subclinical atherosclerosis and cardiometabolic profile among women with abdominal obesity: a randomized controlled trial. BMC Cardiovasc Disord 2014; 10: $14: 82$.

23. Madsen EL, Rissanen A, Bruun JM. Weight loss larger than $10 \%$ is needed for general improvement of levels of circulating adiponectin and markers of inflammation in 
obese subjects: a 3-year weight loss study. Eur J Endocrinol 2008; 158(2):179-187.

24. Ryan AS, Nicklas BJ, Berman DM, Elahi D. Adiponectin levels do not change with moderate dietary induced weight loss and exercise in obese postmenopausal women. Int J Obes Relat Metab Disord 2003; 27:1066-71.

25. Nicklas BJ, You T, Pahor M. Behavioral treatments for chronic systemic inflammation: effects of dietary weight loss and exercise training. CMAJ 2005; 172:1199209 PubMed.

26. Loria-Kohen V, Fernández-Fernández C, Bermejo LM, Morencos E, Romero-Moraleda B, Gómez-Candela C. Effect of different exercise modalities plus a hypocaloric diet on inflammation markers in overweight patients: a randomised trial. Clin Nutr 2013 Aug; 32(4):511-8.

27. Sheu WH, Chang TM, Lee WJ, Ou HC, Wu CM, Tseng LN, Lang HF, Wu CS, Wan CJ, Lee IT. Effect of weight loss on proinflammatory state of mononuclear cells in obese women. Obesity (Silver Spring) 2008; 16(5):1033-8.

28. Rokling-Andersen MH, Reseland JE, Veierød MB, Anderssen SA, Jacobs DR Jr, Urdal P, Jansson JO, Drevon CA. Effects of long-term exercise and diet intervention on plasma adipokine concentrations. Am J Clin Nutr 2007; 86(5):1293-301.

29. Imayama I, Ulrich CM, Alfano CM, Wang C, Xiao L, Wener MH, Campbell KL, Duggan C, Foster-Schubert KE, Kong A, Mason CE, Wang CY, Blackburn GL, Bain CE, Thompson HJ, McTiernan A. Effects of a caloric restriction weight loss diet and exercise on inflammatory biomarkers in overweight/obese postmenopausal women: a randomized controlled trial. Cancer Res 2012; 72(9):2314-26.

30. Silverman N, Nicklas B, Ryan A. Addition of Aerobic Exercise to a Weight Loss Program Increases BMD, with an Associated Reduction in Inflammation in Overweight Postmenopausal Women. Calcif Tissue Int 2009; 84:257-265.

31. Garanty-Bogacka B, Rać M, Syrenicz M, Gębala A, Walczak M, Syrenicz A. Changes in Serum Adipocytokines and Inflammatory Biomarkers Following One-Year of Exercise Training in Obese Adolescents . J Diabetes Metab. 2012, 3:7: 212-217.

32. Habib P, Scrocco JD, Terek M, Vanek V, Mikolich JR. Effects of bariatric surgery on inflammatory, functional and structural markers of coronary atherosclerosis. Am J Cardiol. 2009; 104:1251-1255.

33. Sledzinski T, Sledzinski M, SmolenskiRT, Swierczyns- ki J. Increased serum nitric oxide concentration after bariatric surgery--a potential mechanism for cardiovascular benefit. Obes Surg 2010; 20:204-210.

34. Moschen AR, Molnar C, Geiger S, Graziadei I, Ebenbichler CF, Weiss H, Kaser S, Kaser A, Tilg H. Anti-inflammatory effects of excessive weight loss: Potent suppression of adipose interleukin 6 and tumour necrosis factor alpha expression. Gut 2010; 59:1259-1264.

35. Laimer M, Ebenbichler CF, Kaser S, Sandhofer A, Weiss H, Nehoda H, Aigner F, Patsch JR. Markers of chronic inflammation and obesity: A prospective study on the reversibility of this association in middle-aged women undergoing weight loss by surgical intervention. Int J Obes Relat Metab Disord 2002; 26:659-662.

36. Garcia de la Torre N, Rubio MA, Bordiu E, Cabrerizo L, Aparicio E, Hernandez C, Sanchez- Pernaute A, DiezValladares L, Torres AJ, Puente M, Charro AL. Effects of weight loss after bariatric surgery for morbid obesity on vascular endothelial growth factor-a, adipocytokines, and insulin. J Clin Endocrinol Metab 2008; 93:4276-4281.

37. Marfella R, Esposito K, Siniscalchi M. Effect of weight loss on cardiac synchronization and proinflammatory cytokines in premenopausal obese women. Diabetes Care 2004; 27:47- 52.

38. Hamdy O, Ledbury S, Mullooly C, Jarema C, Porter S, Ovalle K, Moussa A, Caselli A, Caballero AE, Economides PA. Lifestyle modification improves endothelial function in obese subjects with the insulin resistance syndrome. Diabetes Care 2003; 26:2119-2125.

39. Murakami T, Horigome H, Tanaka K, Nakata Y, Ohkawara K, Katayama Y, Matsui A. Impact of weight reduction on production of platelet-derived microparticles and fibrinolytic parameters in obesity. Thromb Res 2007; 119:45-53.

40. Meckling KA, O'Sullivan C, Saari D. Comparison of a low-fat diet to a low-carbohydrate diet on weight loss, body composition, and risk factors for diabetes and cardiovascular disease in free-living, overweight men and women. J Clin Endocrinol Metab 2004; 89:2717-2723.

41. Keogh JB, Brinkworth GD, Noakes M, Belobrajdic DP, Buckley JD, Clifton PM. Effects of weight loss from a very-low-carbohydrate diet on endothelial function and markers of cardiovascular disease risk in subjects with abdominal obesity. Am J Clin Nutr 2008; 87:567-576.

42. Wegge JK, Roberts CK, Ngo TH, Barnard RJ. Effect of diet and exercise intervention on inflammatory and adhesion molecules in postmenopausal women on hor- 
mone replacement therapy and at risk for coronary artery disease. Metabolism 2004; 53:377-381.

43. Rector RS, Turk JR, Sun GY, Guilford BL, Toedebusch BW, McClanahan MW, Thomas TR. Short-term lifestyle modification alters circulating biomarkers of endothelial health in sedentary, overweight adults. Appl Physiol Nutr Metab 2006; 31:512-517.

44. Sharman MJ, Volek JS. Weight loss leads to reductions in inflammatory biomarkers after a very-low-carbohydrate diet and a low-fat diet in overweight men. Clin Sci (Lond) 2004; 107:365-369.

45. Forsythe CE, Phinney SD, Fernandez ML, Quann EE, Wood RJ, Bibus DM, Kraemer WJ, Feinman RD, Volek JS: Comparison of low fat and low carbohydrate diets on circulating fatty acidcomposition and markers of inflammation. Lipids 2008; 43:65-77.

46. Thomson RL, Brinkworth GD, Noakes M, Clifton PM, Norman RJ, Buckley JD. The effect of diet and exercise on markers of endothelial function in overweight and obese women with polycystic ovary syndrome. Hum Reprod 2012; 27(7):2169-76.

47. Haspicova M, Milek D, Siklova-Vitkova M, Wedellova Z, Hejnova J, Bajzova M, Stich V, Polak J. Post-prandial endothelial dysfunction is ameliorated following weight loss in obese premenopausal women. Med Sci Monit 2011; 17(11):PubMed CR634-639.

48. Plat J, Jellema A, Ramakers J, Mensink RP. Weight loss, but not fish oil consumption, improves fasting and postprandial serum lipids, mark $\urcorner$ ers of endothelial func- tion, and inflammatory signatures in moderately obese men. J Nutr 2007;137: 2635-40

49. Nerla R, Tarzia P, Sestito A, Di Monaco A, Infusino F, Matera D, Greco F, Tacchino RM, Lanza GA, Crea F. Effect of bariatric surgery on peripheral flow-mediated dilation and coronary microvascular function. Nutr Metab Cardiovasc Dis 2012; 22(8):626-34.

50. Lind L, Zethelius B, Sundbom M, Eden Engstrom B, Karlsson FA. Vasoreactivity is rapidly improved in obese subjects after gastric bypass surgery. Int J Obes (Lond) 2009; 33:1390-1395.

51. Nijhuis J, van Dielen FM, Fouraschen SM, van den Broek MA, Rensen SS, Buurman WA, Greve JW. Endothelial activation markers and their key regulators after restrictive bariatric surgery. Obesity (Silver Spring) 2007; 15:1395-1399.

52. Uzun H, Zengin K, Taskin M, Aydin S, Simsek G, Dariyerli N. Changes in leptin, plasminogen activator factor and oxidative stress in morbidly obese patients following open and laparoscopic swedish adjustable gastric banding. Obes Surg 2004; 14:659-665.

53. Walther C, Gielen S, Hambrecht R. The effect of exercise training on endothelial function in cardiovascular disease in humans. Exerc Sport Sci Rev 2004; 32:129-134.

54. Schjerve IE, Tyldum GA, Tjonna AE, Stolen T, Loennechen JP, Hansen HE, Haram PM, Heinrich G, Bye A, Najjar SM. Both aerobic endurance and strength training programmes improve cardiovascular health in obese adults. Clin Sci (Lond) 2008; 115:283-293. 